\title{
A Smart Grid Implementation for an Engineering Technology Curriculum
}

\section{Dr. Reg Pecen, Sam Houston State University}

Dr. Reg Pecen is currently a Quanta Endowed Professor of the Department of Engineering Technology at Sam Houston State University in Huntsville, Texas. Dr. Pecen was formerly a professor and program chairs of Electrical Engineering Technology and Graduate (MS and Doctoral) Programs in the Department of Technology at the University of Northern Iowa (UNI). Dr. Pecen served as 2nd President and Professor at North American University in Houston, TX from July 2012 through December 2016. He also served as a Chair of Energy Conservation and Conversion Division at American Society of Engineering Education (ASEE). Dr. Pecen holds a B.S in EE and an M.S. in Controls and Computer Engineering from the Istanbul Technical University, an M.S. in EE from the University of Colorado at Boulder, and a Ph.D. in Electrical Engineering from the University of Wyoming (UW, 1997). He served as a graduate assistant and faculty at UW, and South Dakota State University. He served on UNI Energy and Environment Council, College Diversity Committee, University Diversity Advisory Board, and Graduate College Diversity Task Force Committees. His research interests, grants, and more than 50 publications are in the areas of AC/DC Power System Interactions, distributed energy systems, power quality, and grid-connected renewable energy applications including solar and wind power systems. He is a senior member of IEEE, member of ASEE, Tau Beta Pi National Engineering Honor Society, and ATMAE. Dr. Pecen was recognized as an Honored Teacher/Researcher in "Who's Who among America's Teachers" in 2004-2009. Dr. Pecen is a recipient of 2010 Diversity Matters Award at the University of Northern Iowa for his efforts on promoting diversity and international education at UNI. He is also a recipient of 2011 UNI C.A.R.E Sustainability Award for the recognition of applied research and development of renewable energy applications at UNI and Iowa in general. Dr. Pecen established solar electric boat R \& D center at UNI where dozens of students were given opportunities to design solar powered boats. UNI solar electric boat team with Dr. Pecen's supervision won two times a third place overall in World Championship on solar electric boating, an international competition promoting clean transportation technologies in US waters. He was recognized as an Advisor of the Year Award nominee among 8 other UNI faculty members in 20102011 academic year Leadership Award Ceremony. Dr. Pecen received a Milestone Award for outstanding mentoring of graduate students at UNI, and recognition from UNI Graduate College for acknowledging the milestone that has been achieved in successfully chairing ten or more graduate student culminating projects, theses, or dissertations, in 2011 and 2005.

He was also nominated for 2004 UNI Book and Supply Outstanding Teaching Award, March 2004, and nominated for 2006, and 2007 Russ Nielson Service Awards, UNI. Dr. Pecen is an Engineering Technology Editor of American Journal of Undergraduate Research (AJUR). He has been serving as a reviewer on the IEEE Transactions on Electronics Packaging Manufacturing since 2001. Dr. Pecen has served on ASEE Engineering Technology Division (ETD) in Annual ASEE Conferences as a reviewer, session moderator, and co-moderator since 2002. He served as a Chair-Elect on ASEE ECC Division in 2011. He also served as a program chair on ASEE ECCD in 2010. He is also serving on advisory boards of International Sustainable World Project Olympiad (isweep.org) and International Hydrogen Energy Congress. Dr. Pecen received a certificate of appreciation from IEEE Power Electronics Society in recognition of valuable contributions to the Solar Splash as 2011 and 2012 Event Coordinator. Dr. Pecen was formerly a board member of Iowa Alliance for Wind Innovation and Novel Development (www.iawind.org/board.php) and also represented UNI at Iowa Wind Energy Association (IWEA). Dr. Pecen taught Building Operator Certificate (BOC) classes for the Midwest Energy Efficiency Alliance (MEEA) since 2007 at Iowa, Kansas, Michigan, Illinois, Minnesota, and Missouri as well as the SPEER in Texas and Oklahoma to promote energy efficiency in industrial and commercial environments.

Dr. Pecen was recognized by State of Iowa Senate on June 22, 2012 for his excellent service and contribution to state of Iowa for development of clean and renewable energy and promoting diversity and international education since 1998.

\section{Dr. Faruk Yildiz, Sam Houston State University}


Faruk Yildiz is currently an Associate Professor of Engineering Technology at Sam Houston State University. His primary teaching areas are in Electronics, Computer Aided Design (CAD), and Alternative Energy Systems. Research interests include: low power energy harvesting systems, renewable energy technologies and education. 


\title{
A Smart Grid Implementation for an Engineering Technology Curriculum
}

\begin{abstract}
A smart grid is defined as an intelligent, adaptive-balancing, self-monitoring power grid that accepts any source of fuel, regardless of fossil or renewable, and transforms it into a consumer's end use with minimum human intervention and maximum reliability. The smart grid also allows the optimization of renewable energy use and minimizes the cumulative carbon footprint. However, synchronization of all operating power plants, including conventional and renewable ones, introduces new challenges due to their various infrastructure, dynamics, and operating characteristics.
\end{abstract}

There has been continuous progress on innovative ways of adopting smart grid schemes to new and existing curriculum in engineering and technology programs. However, the physical space needs and initial cost of distributed generation (DG) systems have caused many institutions to concentrate only on power system simulation-based studies. Hands-on inclusive smart grid applications have increased student interest for electronics and computer engineering technology majors as well as electrical power majors because the subjects include digital and graphical technology-based instrumentation and data acquisition of multiple energy resources.

This paper introduces a smart grid implementation using multiple DG sources that include wind, solar photovoltaic (PV), and hydrogen fuel cells in a junior-level electrical power system class offered in a B.S. in Electronics and Computer Engineering Technology program. The DG sources include a $1 \mathrm{~kW}$ hydrogen fuel cell unit, a $0.5 \mathrm{~kW}$ wind turbine, and a $0.5 \mathrm{~kW}$ solar PV panel array. The DG units are connected to a DC bus bar in which a state-of-the art data acquisition and control interface (DACI) developed by FESTO smart grid technologies constitutes a smart grid implementation supported by a low-voltage data acquisition and control (LVDAC) software for monitoring and recording overall power system operation variables and final synchronization with an $\mathrm{AC}$ grid. This paper reports normal operating and contingency cases of the DG system variables that are synchronized with an AC grid in a smart grid environment. Both DACI and LVDAC modules provide monitoring and recording of multiple variables such as voltage, current, power, and frequency values. The operation of this smart grid scheme indicates that a large-scale DC power storage from multiple DG sources is feasible once reliable battery banks are available. The results of the study are very promising in terms of increasing student interest and enthusiasm for modern electrical power systems that are integrated to a smart grid through a state-of-the art data acquisition and instrumentation system. This paper also reports harmonics and power quality issues caused by a large-size DC to AC inverter connecting the DG modules to the AC grid. This curriculum implementation provides an innovative opportunity for future engineering technology students to gain necessary up-to-date competencies in a smart grid environment.

\section{Introduction}

The need for a knowledgeable workforce in fast innovating next generation power grid development and implementation is essential. As the baby boomers employed in the electrical power systems fields have started to retire, there is an urgent need to recruit and graduate an increasing number of well-educated and well-trained next generation professionals from both 
Associate degree and Bachelor 's degree programs. The fast pace of innovations in electrical grid indicates that the future grid will require the employment of well-educated engineers, engineering technologists, and technicians who have knowledge and skills in the areas of distributed generation (DG), microgrid, power electronics, and advanced storage technologies. These employees will need to apply the latest digital technologies applied to electrical grid, plug-in electrical vehicles, demand side management by blockchain, and a smart grid system that may include all these innovations [1-4].

A smart grid is defined as an intelligent, adaptive-balancing, self-monitoring power grid that accepts any source of fuel (either fossil or renewable) and transforms it into a consumer's end use with minimum human intervention and maximum reliability [3-5]. In addition, the smart grid allows for the optimization of renewable energy use and minimizes the cumulative carbon foot print [3-7]. Synchronization of all operating power plants, including conventional and renewable ones, involves new challenges due to their various dynamics, infrastructure, and operating characteristics. As a result, DG is an emerging approach to provide electric power in the heart of the power system, and this approach depends on the installation and operation of a portfolio of small size, compact, and clean electric power generating units at or near electrical loads [8-10]. The DG of electricity integrates with renewable energy (RE) technologies such as photovoltaic (PV) arrays, wind turbines, micro-hydro turbines, tidal units, biogas systems, and hydrogen fuel cell units [10].

Reed and Stanchina from the University of Pittsburgh urged the need for new curriculum to focus on the emerging technologies in electrical power systems such as smart grid and clean energy integration [11 ]. Their work on smart grid education model approaches in engineering curricula provided one of the best models of engineering education in power electronics and power systems. Grinberg and Safiuddin developed a multi-institutional smart grid laboratory to enhance modern power systems education and to satisfy the needs of new technology as a result of the skills shortages and the aging power engineering professional workforce [12]. Kerestes et al. reported an enhanced workforce development study through a consortium that includes twelve universities, seventeen industry partners, and two national labs in order to enhance curriculum development and education in the study of electrical power and distributed energy resources [13]. Belu et al. suggested methods to revitalize a power engineering program with an enhanced major and a new minor program development, while promoting new concepts of smart grids, energy management, and renewable energy systems with support from local and regional industry [14]. Powell and Hayt developed a low-voltage microgrid for experiments in renewable energy distribution that exposed undergraduate engineering students to power generation, grid, and distributed related topics early in a power curriculum that enhanced the students' understanding of both renewable energy integration as well as conventional grid [15]. There have been other studies on how to attract engineering students to cyber-attacks on the power grid and how to establish green energy and sustainability minors. There have been a number of innovative ways suggested to embed renewable energy concepts into engineering education through unique power system simulations and senior design project implementations [16-19].

The fast growth of integration of renewable energy sources in smart grid technologies requires qualified employees and a workforce at all levels including technicians, engineering technologists, and engineers. This will require individuals to become knowledgeable about what a smart grid is 
and how it functions, as well as the integration of major renewable energy sources such as solar and wind energy systems to the existing grid [18, 20-25].

\section{Program Information}

The Electrical/Electronics and Computer Engineering Technology (ECET) Program is a four-year undergraduate program leading to a Bachelor of Science (B.S.) degree at Sam Houston State University (SHSU). The program benefits from the strong support it receives from a partnership between a major energy services industry and employers of the ECET program graduates. The ECET major prepares students for application-oriented engineering technology careers in circuits, conventional and renewable electrical power, analog and digital electronics, industrial controls, microcomputer, telecommunications, industrial electronics, instrumentation, interfacing, data acquisition, networking and system administration with strong hardware knowledge and skills. The program of study requires core courses in mathematics, physics, and computer programming as well as major courses for practical engineering applications of ECET in industrial settings. In addition to the junior and senior level technical classes, the ECET program incorporates extensive practical laboratory exercises and a variety of industrial-based project experiences. The mission of the ECET Program at Sam Houston State University is to foster future professionals through quality education and application-oriented experiences to contribute to the advancement of hardware, software, and systems engineering. Some of the unique program features can be listed as follows:

- Small size classes and an interactive environment where students can engage in their advisors and professors on a daily basis;

- Flexible course offerings that give students options yet provide sufficient rigor to prepare for a productive career in the ECET discipline,

- The new Fred Pirkle Engineering Technology Center at SHSU houses modern and energy-efficient classrooms and laboratory facilities that provide hands-on laboratory experiences on state-of-the-art equipment and trainers commonly used in industry.

- At SHSU, there are part-time job and internship opportunities for students offered by the local and regional employers in the fields of oil, gas and energy.

- Articulation agreements that SHSU has with nearby community colleges provide transfer credits to qualified students up to 65 semester hours;

- There are several annual competitive scholarships and strong industrial partnerships with a regional energy services company that are offered to students; and

- Dedicated departmental student computer laboratories at SHSU are available with continuously updated software tools;

The Engineering Technology (ET) Department at SHSU also offers an electronics concentration that is intended to provide knowledge and hands-on skills of hardware and software to other ET majors. Students in different majors such as computer science, physics, design, construction, and the recently-proposed mechanical engineering technology field can benefit from the electronics concentration. The overall requirement of a graduation for a B.S. degree in ECET is 122-123 semester hours.

\section{Smart Grid Integration to Electrical Power Systems Curriculum}

The implementation of DG sources to a conventional grid may result in many advantages such as providing high efficiency and reduction of a carbon foot print, reducing transmission and distribution losses, supporting the local grid, and enhancing the system stability [20]. However, 
application of individual DG may also result in new challenges, and there are many research problems to be solved in the grid-tied operation of conventional and DG fields [21-27]. When the grid includes DG sources, the term smart grid becomes an umbrella term used to refer to new technologies that address today's electrical grid challenges associated with grid reliability, smooth integration of renewables, and disturbance detection that may arise from any section of the grid, from an inverter failure from a large PV farm to a tree branch short circuit of the alternative current (AC) transmission line in the grid [26-27].

Smart grid systems are more reliable and efficient due to their complementary cleaner energy generation modes, in addition to conventional base power generation. They are also capable of monitoring, controlling, supplementing power demand, and distributing the power throughout all connected nodes. A combination of smart microgrids is expected to replace the conventional electrical power system to enhance reliability, accessibility, flexibility, and power quality [23-27]. Figure 1 depicts a basic microgrid built by solar PV and wind turbine sources [28]. The wind turbine generator used in this project is a three-phase synchronous generator with rectified DC output of $12 \mathrm{~V}$ and $7 \mathrm{~A}$ at a rated condition of $10 \mathrm{mph}$ wind speed.

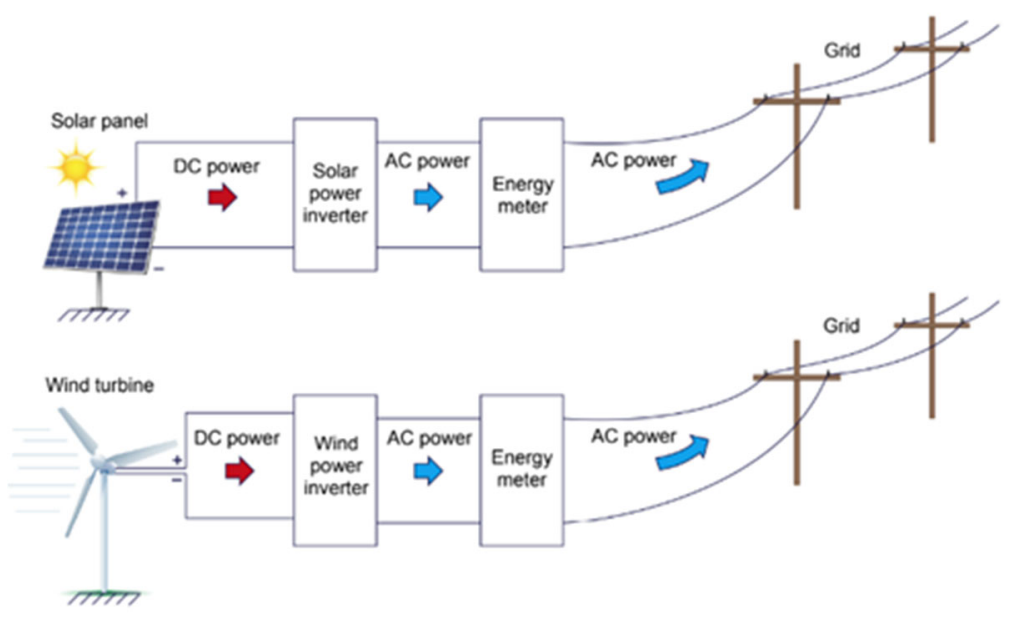

Figure 1. Basic integration of PV and wind-based microgrid to the conventional grid [28].

Figure 2 shows distributed resources of a hybrid $3 \mathrm{~kW}$ wind turbine and solar PV array and a 1 kW Hydrogen fuel cell (HFC) module available in the department's indoor and outdoor laboratories. A smart grid technology training system developed by Festo Corporation ${ }^{\mathrm{TM}}$ was used in this curriculum development work as shown in Figure 3 [28].

Figure 3 depicts a functional block diagram of SHSU's microgrid that includes solar PV, a wind turbine, and an HFC power system integrated to a local utility company. The hybrid solar PV and wind turbine power system were designed and built in the past academic years by senior students and faculty. Students designed and built several DC to DC chopper circuit boards that connected lower voltage outputs from distributed resources to the DC input of the FESTO smart grid training system. The faculty and students established the smart grid test bench using a wind and solar PV power system that had been constructed in the past academic years as seen in Figure 2 and Figure 3. This scheme provides the student with an understanding of the necessary fundamentals for further inclusion of multiple energy generation sources developed in a smallscale smart grid system during various operating times and demand. 


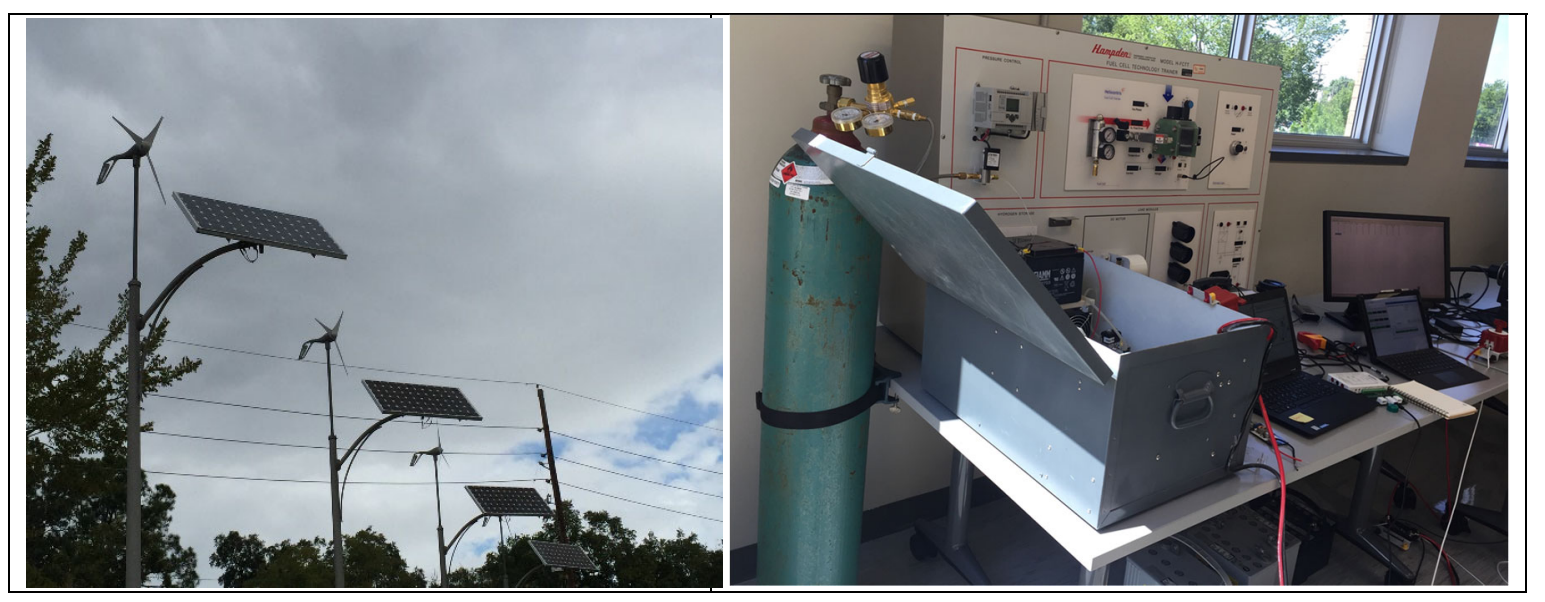

Figure 2. Solar PV, wind turbine, and hydrogen fuel cell power system that establishes a microgrid to smart grid test bench.

The test bench used in this study uses DC electrical signals from solar PV, wind, and HFC power modules that also includes battery, boost chopper, an LC filter, and a single-phase PWM inverter as seen in Figure 4. The Low Voltage Data Acquisition and Control (LVDAC) Instrumentation module allows for real time measurement and monitoring of voltage, current, power, power factor, phase shift, and other meter settings as shown in Figure 3 and Figure 4.

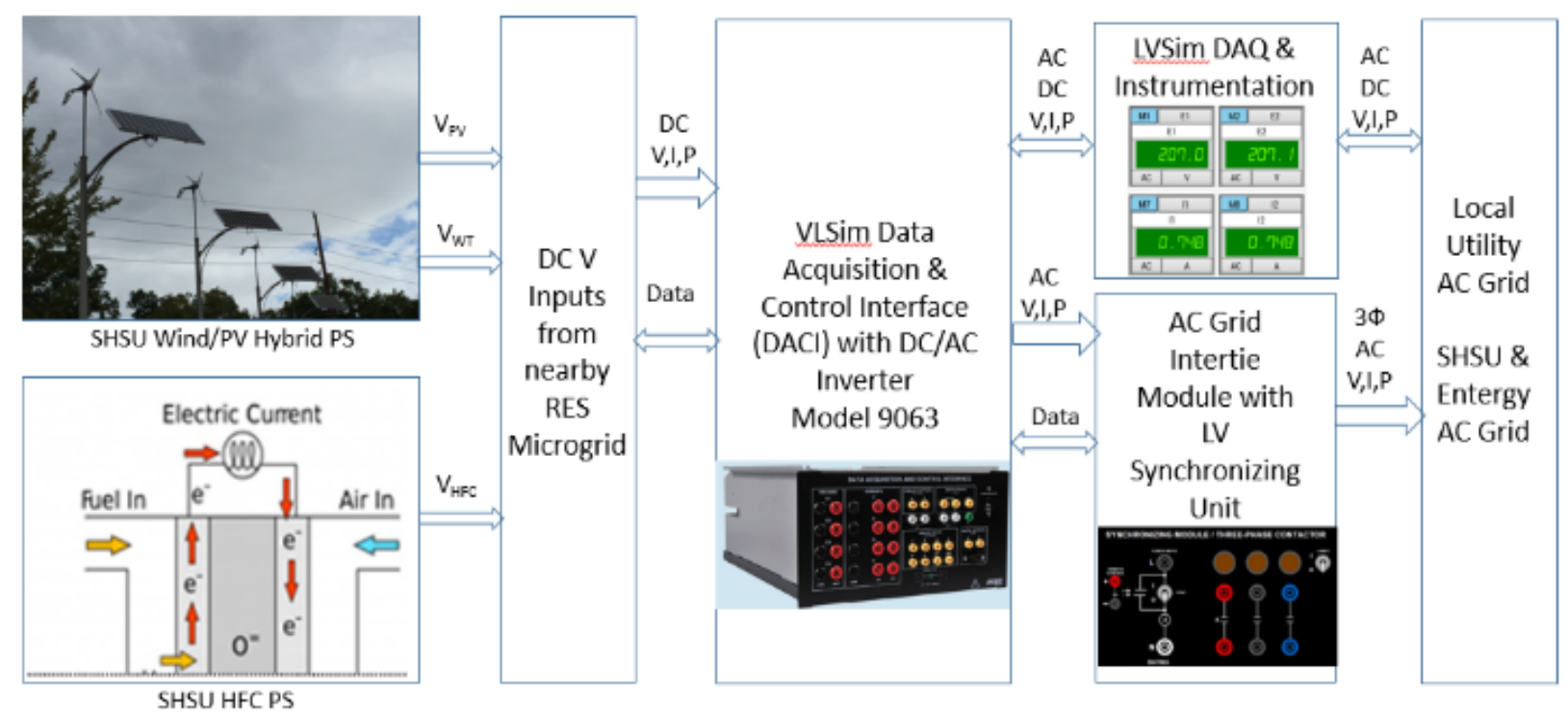

Figure 3. Functional block diagram of the SHSU microgrid containing solar PV, wind turbine, and HFC power system integrated to local utility company

The LVDAC module is an effective tool for precise data acquisition and analysis. Various controls within each function of the LVDAC module and the Four-Quadrant Dynamometer are available, such as the solar power inverter, home energy production (HEP) window, phasor analyzer, oscilloscope, etc. The Festo Smart Grid Technologies Training System in Figures 3 and 4 includes the following modules: 
- An insulated DC to DC converter.

- A resistive load is used to simulate loads at the user end of an energy system similar to resistive loads at residential buildings.

- The Data Acquisition and Control Interface (DACI) allows for the monitoring of various types of data in an experiment. It may also be used to control aspects of an experiment when used with the LVDAC software.

- A low frequency transformer can be used for isolation between $\mathrm{DC}$ and $\mathrm{AC}$ sides of a power system when galvanic isolation is required and the DC to DC converter is not used and to achieve the voltage measurements necessary for proper operation.

- An IGBT Chopper/Inverter is used to boost DC voltage to the necessary DC bus voltage for inversion to AC. This can also be used as a buck chopper to reduce voltage to meet the DC bus needs. This module allows for electrical power flow in either direction.

- Filtering inductors/capacitors are used to smooth out the current waveform on the AC side of the system. The capacitors improve power factor and keep constant voltage. The unit contains two $2 \mathrm{mH} 5 \mathrm{~A}$ inductors, one $50 \mathrm{mH} 5 \mathrm{~A}$ inductor, and two capacitors, one $210 \mu \mathrm{F}$, and one $5 \mu \mathrm{F}$ rating.

- An AC power network interface provides $\mathrm{AC}$ power from the inverter that can be used to operate a load or, as a module, to inject power back to the AC grid.

- The power supply that is a four-quadrant dynamometer has many functions available to generate power when simulating PVs and other renewable resources.

- A lead acid battery pack serves as a power source, as well as a bank for power storage when being implemented in a smart grid.

- The power supply provides 3-phase power and AC voltage of $24 \mathrm{~V}$ to the system units.

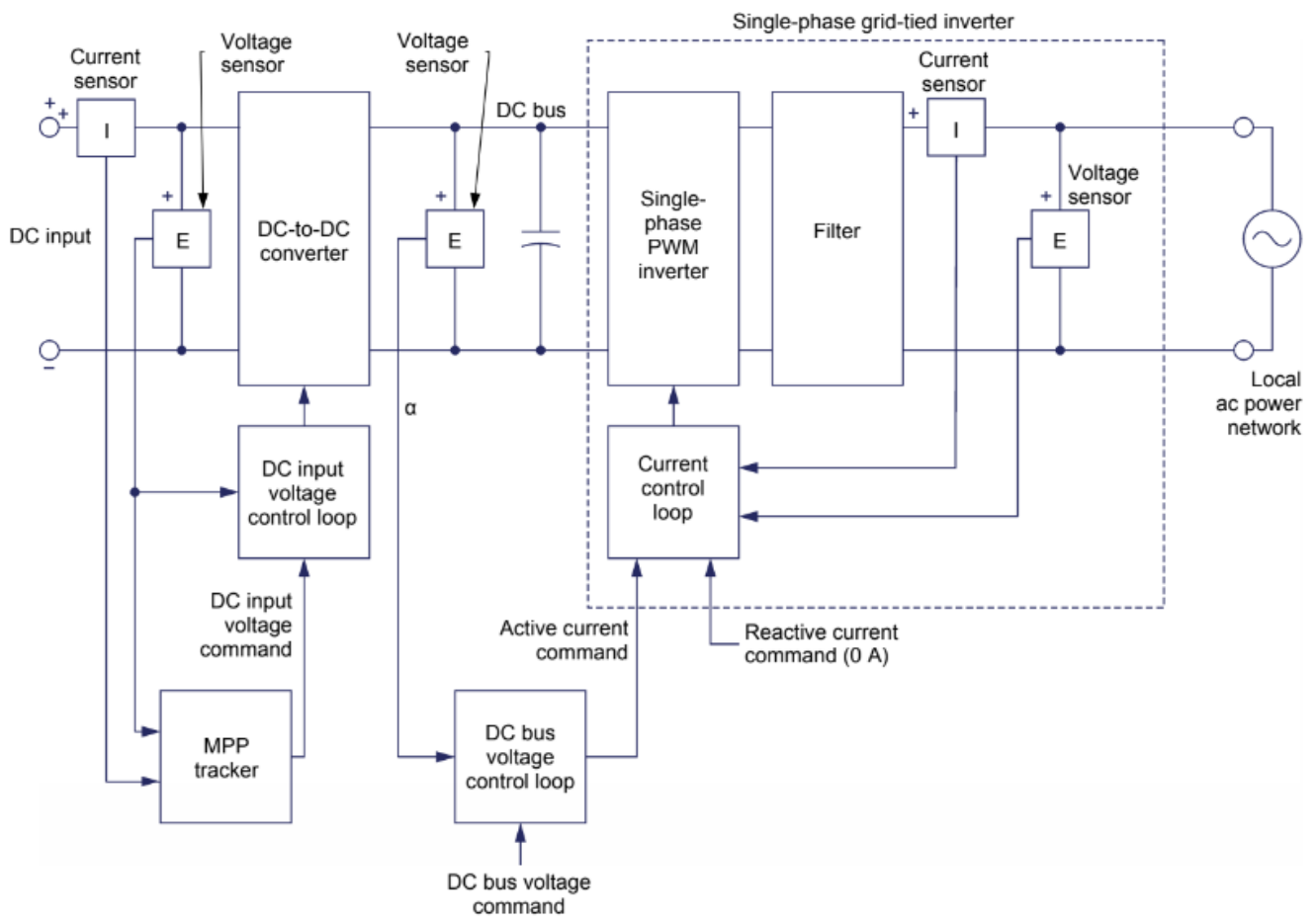

Figure 4. The LVSim Data Acquisition and Control Interface (DACI) and Grid Intertie system developed by FESTO used in this microgrid system [28]. 
Figure 5 depicts the smart grid test bench system with an indoor HFC module and additional instruments such as a Fluke 435 power quality analyzer, additional voltage, current, NI myDAQ board for specific data monitoring and control, various load resistors, and metering.

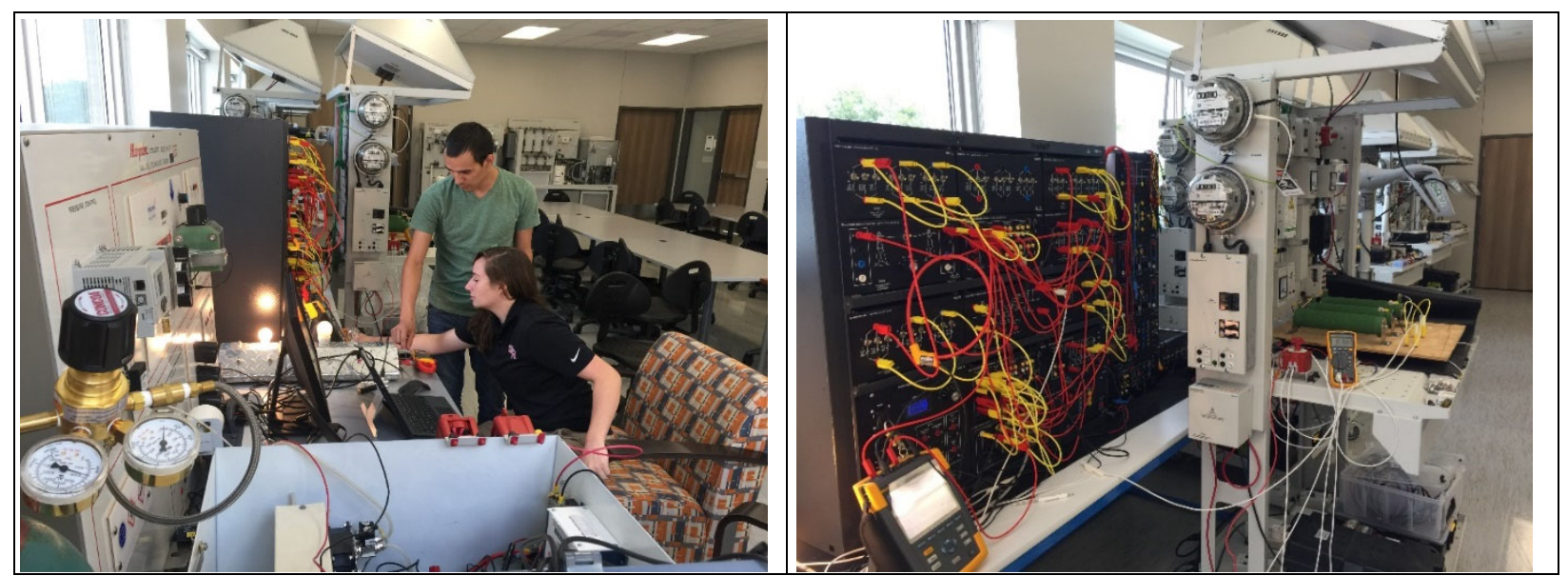

Figure 5. Students are working on the smart grid test bench.

\section{Learning Outcomes of the Electrical Power and Machinery Course}

The students in the ECET program are expected to gain knowledge and skills of distributed energy and microgrid operation, battery storage, energy conversion, and conservation techniques in the conventional and renewable energy systems [28]. During the course and the laboratory projects, students will become familiar with the equipment and the components used in grid-tied and standalone energy systems such as PV panels, wind turbines, a variety of metering and protection devices, power transformers, a buck-boost converter, a single-phase inverter/rectifier, an isolation transformer, an insulated DC-to-DC Converter, data acquisition and control interface (DACI), and the low voltage data acquisition and control (LVDAC) system software by Festo-Didactic, Inc. ${ }^{\mathrm{TM}}$ [28]. Upon completion of the course, students will be able to provide assessment data for the outcomes that will help the ECET program's accreditation efforts on data collection and assessment aligned with the ABET-ETAC criteria.

- Apply the theory of electrical machines-motors-generators-transformers - to the practical industrial settings with appropriate drives and controls;

- Demonstrate the theory of single phase and three phase electrical power, stationary and rotating electrical machines operating on $\mathrm{DC} / \mathrm{AC}$, and their relevant control systems;

- Establish the concepts of electrical power production, transmission, application, and the control relating to the industrial and commercial settings;

- Practice fundamentals of the National Electric Code (NEC) requirements and electrical safety rules for electrical systems;

- Apply creativity in the design of components and systems based on specified requirements and known design techniques;

- Design and carry out experiments and tests, analyze and interpret data, and make iterative improvements by using safe and technically correct laboratory methods; and

- Collaborate with each other in laboratory and classroom settings to work effectively in teams. 


\section{Case Studies and Laboratory Work on the Smart Grid testbench}

Figure 6 depicts current signals scaled down to low currents due to sensor capabilities. The normal operation conditions indicate that source currents from wind turbine, hydrogen fuel cell, and solar PV are all in rated values except the current from the PV sources indicates a reduction between the time frame of $32 \mathrm{~s}$ to $77 \mathrm{~s}$ due to variable solar radiation conditions.

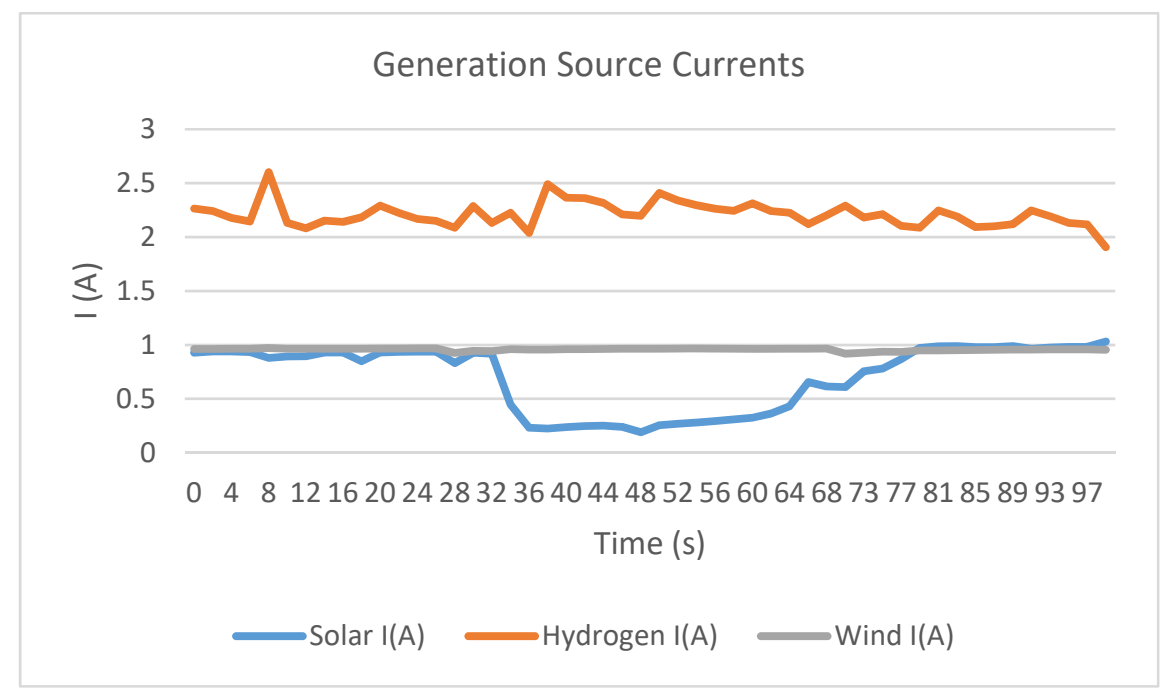

Figure 6. Rated source currents from solar PV, wind turbine, and HFC modules.

Figure 7 indicates normal operation and multiple contingency studies including a major AC load switching on and off, and a hydrogen failure case. The grid-tied DG system satisfies a stable operation after disturbances occur.

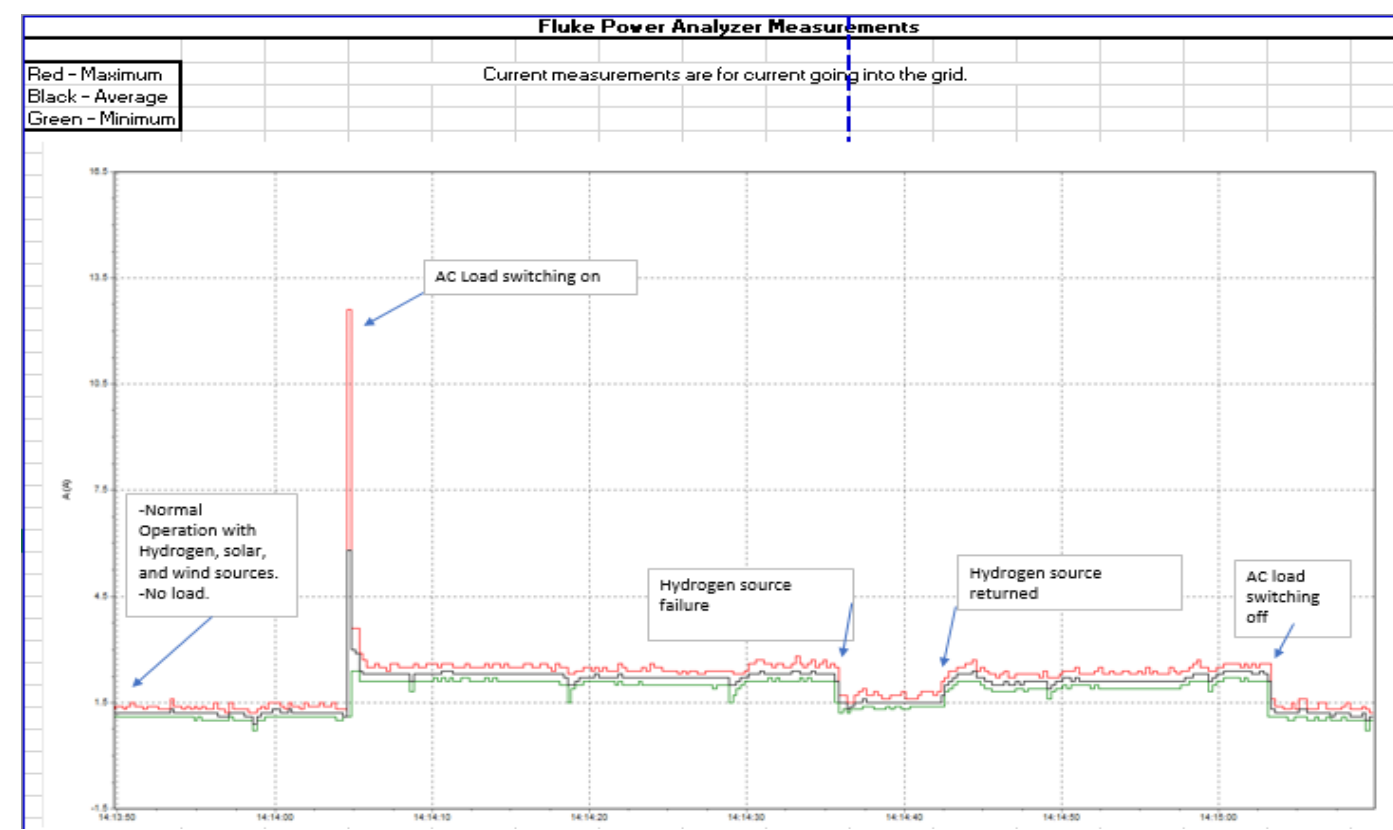

Figure 7. Normal operation and contingency cases recorded by a Fluke 435 Series II power quality and energy analyzer. 
Harmonics voltages and currents are integer multiples of fundamental frequency of $60 \mathrm{~Hz}$, and both odd and even harmonics can be produced in electrical power systems due to non-linear loads, operations of inverters and rectifiers, iron-core saturation issues in the transformers, and, specifically, adjustable speed drives used in industrial environments. If not monitored, controlled, and reduced, the harmonics may cause serious damage such as overheating and nuisance tripping in the power systems. The AC grid current and total harmonic distortion for the current $\left(\mathrm{THD}_{\mathrm{i}}\right)$ are shown in Figure 8. The THDi values fluctuate above the maximum allowed values of the IEEE 519 requirements of 5\% due to the inverters in the system. Students are encouraged to consider harmonic filters in order not to exceed a maximum of 5\% THD values.

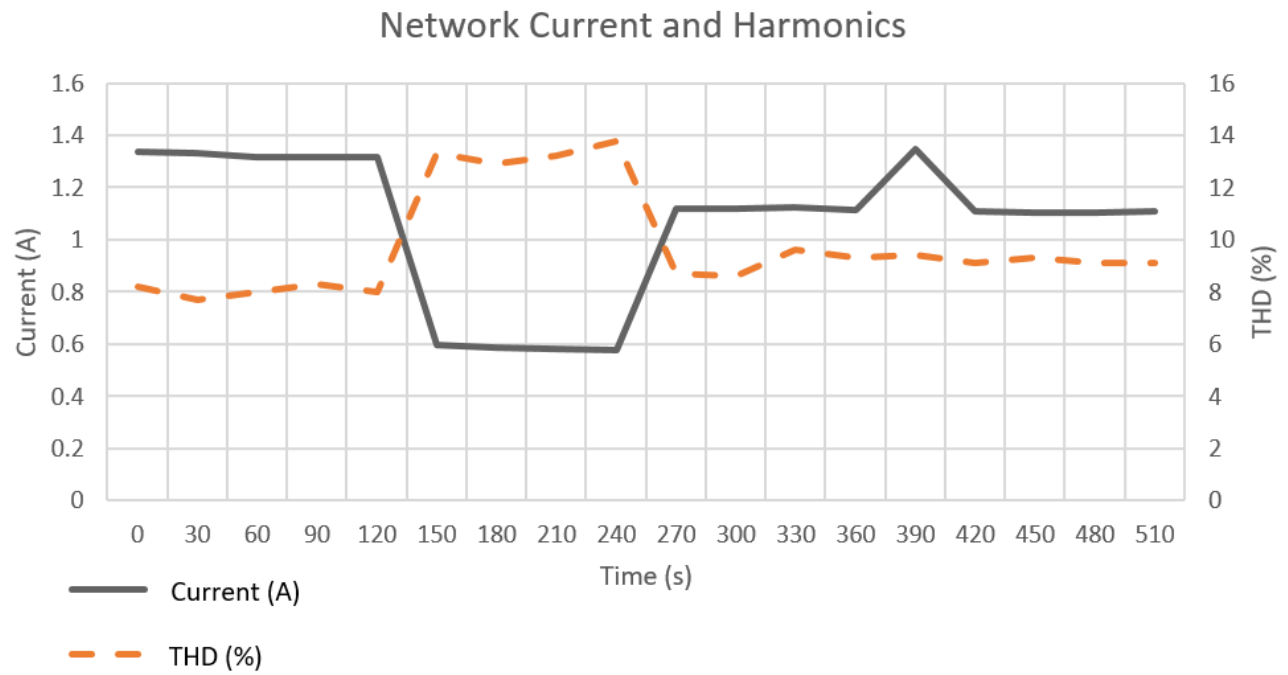

Figure 8. AC grid current and THDi for the studied smart grid system.

Figure 9 depicts total harmonic distortion values for voltage waveforms; they are all below $4 \%$ values that satisfy the IEEE 519 requirements [29].

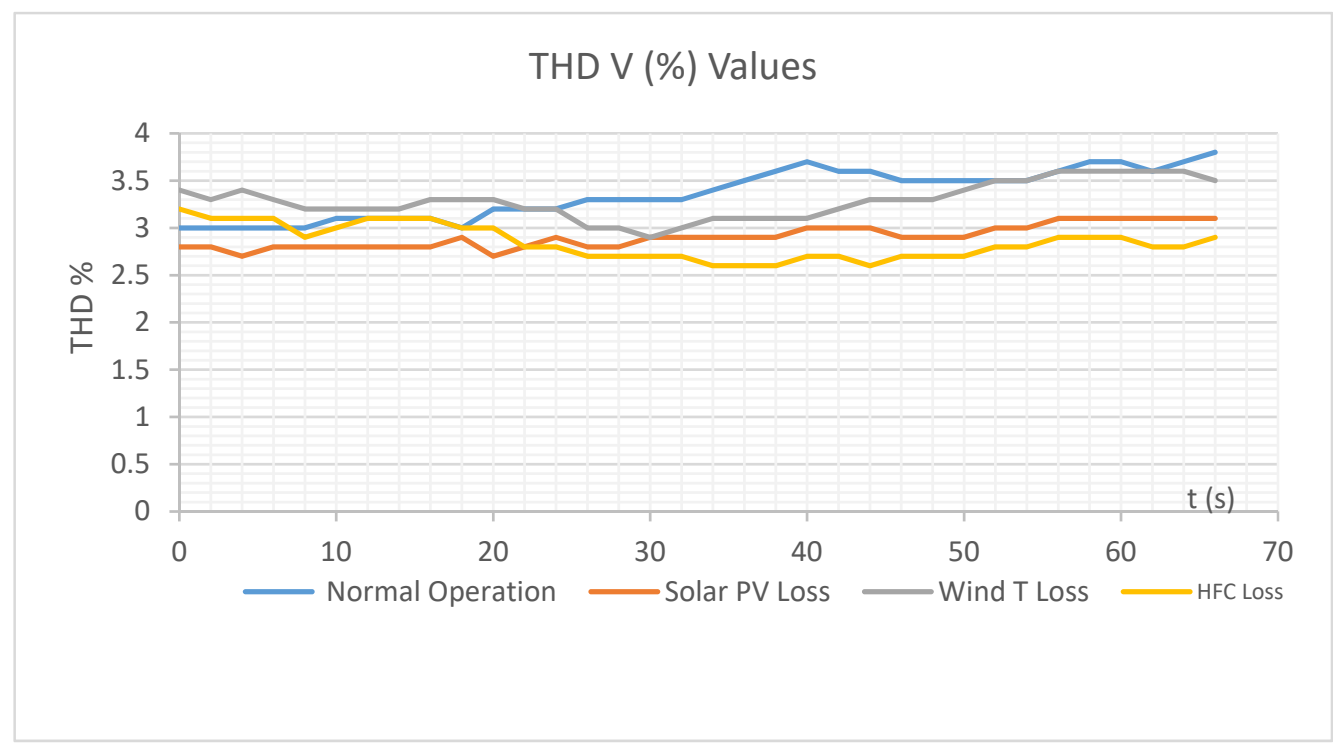

Figure 9. Total harmonic distortion for voltage $\left(\mathrm{THD}_{\mathrm{v}}\right)$ of the smart grid system for different case studies obtained by a Fluke 435 Series II power quality and energy analyzer. 


\section{Course Assessment}

The Office of Academic Planning and Assessment at Sam Houston State University coordinates the institution's well-established student ratings of instruction (SRI) instrument that is called the IDEA evaluation process. This instrument has a 1.0 to 5.0 scale, where 5.0 is the highest ranking. In addition to the university's set general learning objectives, additional learning objectives aligned with ABET-ETAC Criteria 3 are also included in the IDEA evaluation process. The IDEA evaluation process allows instructors to enter their own learning objectives aligned with the appropriate accreditation criteria and ranks the objectives as minor, important, and essential. Student ratings of learning objectives will be reported at the end of the spring semester, and they will be ready during the ASEE annual conference presentation. The assessment data will be used to improve the course objectives and goals as well as provide feedback to the University's regional accreditation institution, The Commission on Colleges of the Southern Association of Colleges and Schools (SACSCOC). The criteria for accrediting engineering technology programs for 20182019 (ABET-ETAC) are in two sections - general and program specific criteria [30]. The general criterion 5 describes that the curriculum must effectively develop certain subject areas in support of student outcomes and program educational objectives [30]. Similarly, ABET-ETAC program criteria for B.S. programs Section (c) requires "the ability to analyze, design, and implement one or more of the following: control systems, instrumentation systems, communications systems, computer systems, or power systems" [30]. Both theory and the laboratory projects for power systems and instrumentation-data acquisition curriculum are covered when the students are introduced to microgrid and smart grid system that is shown in Figure 3.

\section{Conclusion}

This paper described course objectives, learning outcomes, and sample curriculum material covering lecture, laboratory, and project activities for a new core course titled ETEE 4369 Electrical Power and Machinery for the purpose of introducing distributed generation, microgrid, and smart grid concepts to undergraduate students in an engineering technology curriculum. It is offered in the B.S. in Engineering Technology and the B.S. in Electrical/Electronics and Computer Engineering Technology Programs at SHSU where a strong university-energy industry partnership requires students to gain knowledge and skills in modern electrical power systems. Student interest to smart grid applications is very high, and the related student assessments will be reported at the end of the spring 2019 semester by the institution's well-established student ratings of instruction (SRI) instrument, the IDEA evaluation process. The assessment data will be ready for the presentation material during the ASEE Annual Conference. In addition, course surveys on overall class structure and learning objectives will be reported as well. The outcomes of this curriculum enhancement by smart grid are:

(a) A well-established electrical power systems and machinery course with smart grid applications is added to the B.S. in Engineering Technology curriculum;

(b) This class will help to collect assessment data for the criteria 3 of the ABET-ETAC requirements;

(c) Students are exposed to real-time data acquisition and instrumentation applications in smart grid using FESTO's LVDAC as well as National Instrument's LabVIEW ${ }^{\mathrm{TM}}$-based myDAQ board and a number of voltage, current, solar radiation (pyranometer), and wind speed (anemometer) sensors. 


\section{References}

[1] Justo, J.J., Mwasilu, F., Lee, J., \& Jung, J.W. (2013). AC-microgrids versus DC-microgrids with distributed energy resources: A review. Renewable and Sustainable Energy Reviews, 24 (C), 387-405. [2] El-Khattam, W., Salama, M.A. (2004). Distributed generation technologies, definitions and benefits. Elsevier Journal of Electric Power Systems Research, 71(2), 119-128.

[3] Celeita, D., Hernandez, M., Ramos, G., Penafiel N., Rangel M., \& Bernal J.D. (2016). Implementation of an educational real-time platform for relaying automation on smart grids. Elsevier Electrical Power System Research, 130 (12), 156-166. Retrieved from http://dx.doi.org/10.1016/j.epsr.2015.09.003

[4] Cardenas, J.A., Gemoets, L., Ablanedo Rosas, J.H. \& Sarfi, R. (2014). A literature survey on Smart Grid distribution: an analytical approach. Journal of Cleaner Production, 65 (C), 202-216.

[5] Uludag, S., Lui, K. S., Ren, W., Nahrstedt, K. (2016). Secure and scalable data collection with time minimization in the smart grid. IEEE Transactions on Smart Grid, 7(1), 43-54.

[6] Luo, Y., Shi, L., Tu, G. (2014). Optimal sizing and control strategy of isolated grid with wind power and energy storage system. Energy Conversion Management, 80, 407-415.

[7] Wadghule, T.M. (2013). A review of plug-in hybrid electric vehicles as new storage \& transportation system for smart grid. International Journal of Engineering Research \& Technology, 2(3), 1-7.

[8] Yong, J.Y., Ramachandaramurthy, V.K., Tan, K.M., Mithulananthan, N. (2015). A review on the state-of-the-art technologies of electric vehicle, its impacts and prospects. Renewable Sustainable Energy Review, 49, 365-385. Retrieved from https://doi.org/10.1016/j.rser.2015.04.130

[9] Sandeep, K., Saurabh, C. (2018). Smart operations of smart grids integrated with distributed generation: A review. Elsevier, Journal of Renewable \& Sustainable Energy Review, 81, 524-535.

[10] Yoldas, Y., Onen, A., Muyeen, S.M., \& Alan, I. (2017). Enhancing smart grid with Microgrids: Challenges and opportunities. Elsevier Renewable and Sustainable Energy Reviews, 72, 205-214. Retrieved from DOI:10.1016/j.rser.2017.01.064

[11] Reed, G.F., Stanchina (2010). W., Smart Grid Education Models for Modern Electric Power System Engineering Curriculum, IEEE Power and Energy Society General Meeting, DOI:

10.1109/PES.2010.5589617. https://www.researchgate.net/publication/261238665

[12] Grinberg, I. Y., \& Safiuddin, M. (2012, June), Multi-institutional Smart Grid Laboratory Paper presented at 2012 ASEE Annual Conference \& Exposition, San Antonio, TX. https://peer.asee.org/21713

[13] Kerestes, R. J., \& Qu, Z., \& Turgut, D. (2018, June), Enhanced Workforce Development via the 2017 FEEDER Student Summer Program Paper presented at 2018 ASEE Annual Conference \& Exposition ,

Salt Lake City, Utah. https://peer.asee.org/30423

[14] Belu, R. G. et al. (2018, June), Development and Implementation of a Power and Energy

Engineering Minor with Limited Resources: First Results and Lessons Learned Paper presented at 2018

ASEE Annual Conference \& Exposition, Salt Lake City, UT. https://peer.asee.org/30318

[15] Powell, H. C., \& Hayt, B. (2018, June), Developing a Low-voltage Microgrid for Experiments in Renewable Energy Distribution Paper presented at 2018 ASEE Annual Conference \& Exposition, Salt Lake City, UT. https://peer.asee.org/30291

[16] Kollmer, J. D., \& Irwin, R. S., \& Biswas, S. K., \& Saad, W., \& Sarwat, A. I., \& Bai, L. (2017, June), Development of an Experimental Platform for Analysis of Cyber Attacks on the Power Grid Paper presented at 2017 ASEE Annual Conference \& Exposition, Columbus, OH. https://peer.asee.org/28167 [17] Ciobanescu Husanu, I. N., \& Chiou, R. (2017, June), Embedding Global Energy Education into Engineering Technology Curricula: The Development and Implementation of Green Energy and Sustainability ET Minor Paper presented at 2017 ASEE Annual Conference \& Exposition, Columbus, OH. https://peer.asee.org/28216

[18] Pecen, R., Hall, T., Chalkiadakis, F., \& Zora, A. (2003). Renewable energy based capstone design applications for an undergraduate engineering technology curriculum. Paper presented at $33^{\text {rd }}$ ASEE and IEEE Frontiers in Education Conference, Session S1E-21, Boulder, CO. Retrieved from http://icee.usm.edu/ICEE/conferences/FIEC2003/papers/1551.pdf 
[19] Farook, O., \& Agrawal, J. P., \& Kulatunga, A., \& Ahmed, A., \& Yu, W., \& Lee, Y., \& Alibrahim, H. A. (2017, June), Freshman Experience Course in Electrical and Computer Engineering Technology Emphasizing Computation, Simulation, Mathematical Modeling, and Measurements Paper presented at 2017 ASEE Annual Conference \& Exposition, Columbus, OH. https://peer.asee.org/28388

[20] Mwasilu, F., Justo, J.J., Kim, E.K., Do, T.D., \& Jung, J.W. (2014). Electric vehicles and smart grid interaction: A review on vehicle to grid and renewable energy sources integration. Elsevier Renewable and Sustainable Energy Review, 34(C), 501-516.

[21] Gomez, T. et al. (2011). Regulatory framework and business models for charging plug-in e-vehicles: Infrastructure, agents, and commercial relationships. Energy Policy 2011, 39 (10), 6360-6375.

[22] Sortomme, E., El-Sharkawi, M.A. (2011). Optimal charging strategies for unidirectional vehicle-togrid. IEEE Transactions on Smart Grid, 2 (1), 131-138.

[23] Vandoorn, T.L., Vandevelde, L. (2014). Contribution of Microgrids to the Development of the Smart Grid. D. Bakken, K. Iniewski (Eds.), Smart grids, Clouds, Communications, Open Source, and Automation (pp. 191-211). CRC Press.

[24] Khodayar, M.E., Wu, H. (2015). Demand forecasting in the smart grid paradigm: Features and challenges. Elsevier, The Electricity Journal, 28 (6), 51-62. Retrieved from

https://www.sciencedirect.com/science/article/pii/S1040619015001268

[25] Amalorpavaraj, R. A. J, et al. (2018). Smart grid and power quality issues. F. Hina, N. Parbaharan, K. Akhtar, M. Saad, \& J. Jackson (Eds.), Hybrid-Renewable Energy Sys. in Microgrids (pp.195-202).

Woodhead Publ. Series in Energy. Retrieved from https://doi.org/10.1016/B978-0-08-102493-5.00010-8

[26] Fang, X., et al. (2012). Smart grid - The new and improved power grid: A survey. IEEE

Communications Surveys \& Tutorials, 14 (4), 944-980. Retrieved from

https://ieeexplore.ieee.org/document/6099519/

[27] Pinnangudi, B., Kuykendal, M. \& Bhadra, S. (2017). Smart Grid Energy Storage. B.W. D'Andrade (Ed.), The Power Grid (pp. 93-135). Elsevier Academic Press. Retrieved from https://www.sciencedirect.com/book/9780128053218/the-power-grid

[28] FESTO Electricity and New Energy Manual, LabVolts Festo Didactic Ltd, Quebec Canada, 2012 [29] IEEE Recommended Practice and requirements for Harmonic Control in Electric Power Systems, IEEE Power and Energy Society (PES), IEEE Std. 519 - 2014 (Revision of IEEE Std 519-1992). [30] ABET-ETAC Criteria for Accrediting Engineering Technology Programs. (2018-2019). Retrieved from https://www.abet.org/accreditation/accreditation-criteria/criteria-for-accrediting-engineeringtechnology-programs-2018-2019/ 